\title{
Effects of PGPR, AMF and Trichoderma Applications on Adaptation Abilities to Different Biotic and Abiotic Conditions in Medicinal and Aromatic Plants
}

\author{
Ebru Şirin ${ }^{1, a, *}$, Yaşar Ertürk ${ }^{1, b}$, Ahmet Kazankaya ${ }^{1, c}$ \\ ${ }^{I}$ Department of Horticulture, Faculty of Agriculture, Kırşehir Ahi Evran University, 40100 Kırşehir, Turkey \\ *Corresponding author \\ A R T I C L E I N F O A B S T R A C T \\ Review Article \\ Medicinal and aromatic plants are valuable sources of herbal products worldwide due to their \\ secondary metabolite content, high antioxidant activities and many other biological activities. As a \\ result of the developing technology, the demand for natural active substances obtained from plants \\ has increased. For use, plants collected from nature do not have the desired quality standards. For \\ Received : 09/08/2021 \\ Accepted : 18/11/2021 \\ this reason, sustainability can be achieved by using microbial inoculants as well as many \\ biotechnological and molecular approaches such as micro propagation, synthetic seed technology \\ to increase the yield and quality standards of medicinal and aromatic plants. Thanks to microbial \\ inoculants, yield increase can be realized and at the same time, product quality can be contributed \\ due to increased soil quality. In this review, it was aimed to evaluate the important roles of plant \\ growth promoting rhizobacteria (PGPR), Arbiscular mycorrhizal fungi and Trichoderma inoculants \\ Keywords: \\ Medicinal and aromatic plants \\ Plant growth \\ PGPR \\ AMF \\ Trichoderma spp \\ in increasing productivity, nutrient uptake and resistance of medicinal and aromatic plants to \\ environmental stresses in the light of literature. In this review, the variation in the resistance of \\ plants to environmental stresses is summarized by evaluating the ultimate effects of microbial \\ inoculants alone and in combination. In addition, it has been added to the evaluation in studies to \\ prevent the decrease of secondary metabolite content formed under environmental stress conditions \\ in medicinal and aromatic plants by microorganisms.
}

\section{Introduction}

Medicinal and aromatic plants are grouped according to their families, taxonomic categories, morphological and pharmacolic features, active ingredients, consumption and use, organs used and pharmacological effects. Most medicinal plants are endemic species and their medicinal properties are mainly due to the presence of secondary metabolites that respond to stimuli in natural environments and cannot be expressed under culture conditions (Figueiredo and Grelle, 2009).

Medicinal aromatic plants, most of which are endemic species, have increased their use worldwide due to their secondary metabolite content that responds to stimuli in natural environments (Cole et al., 2007).

Primary metabolites refer to compounds of nucleic acids, proteins, carbohydrates, fats and lipids. Primary metabolites are found in all plants and perform metabolic activities by participating in nutrition and reproduction (Croteau et al., 2000). Primary metabolism refers to the processes that produce the carboxylic acids of the Krebs cycle. Secondary metabolites, on the other hand, are not essential for life, but contribute to the survival of the species (Pagare et al., 2015). Of the secondary metabolites, carotenoids and flavonoids play a role in cell pigmentation in flowers and seeds by attracting pollinators. Therefore, they also participate in plant reproduction (Winkel-Shirley, 2001).

Secondary metabolites are synthesized in specific ways by specific biosynthetic enzymes in tissues, organs, and growth parts of the plant. Although the functions of secondary products are differing, those which are cytotoxic against microbial pathogens, therefore they are used as antimicrobial agents in medicine (Briskin, 2000; Goldman, 2001).

Medicinal and aromatic plants encounter many problems arising from both biotic and abiotic stress conditions in the environment they grow due to the medicinal metabolites they contain. In a given environmental condition and on a selected genotype, agronomic factors deeply affect plant growth and quality. Pointed out that secondary metabolites are fundamentally 
produced by genetic pathways, although their biosynthesis is strongly influenced by environmental factors (Yazdani and Jamshidi, 2002). Biotic factors are stress factors resulting from fungal, bacterial and viral infection of microorganisms and attacks by harmful animals. Abiotic factors are environmental factors such as water, temperature, radiation, chemicals, magnetic and electrical fields. (Lichtenhaler, 1996). This means that biotic and abiotic stress factors highly affect their growth parameter, essential oil yields and chemical composition. Among the abiotic environmental stress factors, salinity and drought have the most important effect on medicinal plants (Aziz et al., 2008; Heidari et al., 2008).

An abiotic stress reduces the uptake and diffusion of $\mathrm{CO}_{2}$ and alters different biochemical reactions, which further inhibits photosynthesis (Flexas et al., 2004). These stresses are the prime causes of crop failure and decreasing the yield by more than 50\% (Bray et al., 2000) and pressurize the sustainability of agriculture sector.

Microbial based bio stimulants have been crucial since the beginning of agriculture (i.e., Rhizobium in legumes) and current expectations include its commercialization as a complementary to crop nutrition. The beneficial effects of microorganisms to plants depend upon sophisticated nutritional and chemical signaling as well as soil and climate factors. Plant roots release sugars, organic acids, amino acids and phenolics, which affect the composition of rhizosphere communities, leading to beneficial relationships. (Ortíz-Castro et al., 2009).

The plant rhizosphere is a region of intense microbial activity where many microorganisms colonize on and around the roots of growing plants have an ecological importance. Various groups of bacteria, mycorrhizae and other groups of microorganisms are associated with the root systems of all higher plants. In studies on the interactions of beneficial microorganisms with the plant, it has been reported that depending on the plant and microorganism species and ecology, it may have either positive, negative, or neutral effects on host plant (Glick et al., 1999; Ertürk et al., 2008; Ertürk et al., 2010). Bacteria, one of the largest groups of microorganisms can promote plant growth by attaching to the outer surface of the plant, such as roots (rhizosphere) or leaves (phyllosphere), or by forming endophytic relationships on the inner surfaces of the plant. It has been suggested that PGPR can increase plant growth by reducing the ethylene level in the plant. In these cases, the immediate precursor of ethylene is 1 aminocyclopropane-1-carboxylate (ACC). This compound is hydrolyzed by bacteria expressing ACC-deaminase activity. The products of this hydrolysis, ammonia and $\alpha$ ketobutyrate, are used as nitrogen and carbon sources by bacteria that break down the ACC (Glick et al., 1999).

Another group of microorganisms which are active in the plant rhizosphere are arbuscular mycorrhizal fungi. Mycorrhiza is a term derived from the Greek words mikes (fungus) and riza (root), meaning "root fungus". The term mycorrhiza refers to the cooperation or symbiosis between plants and fungi that colonize the cortex tissue of the roots during the active plant development phase. This cooperation is characterized by the flow of carbon, which is the production of plants to the fungus and the nutrients taken by the fungus to the plant. They interact with a wide variety of other soil organisms at the root or in the soil's rhizosphere. Some form a symbiotic association and in turn alter the host physiology (Fitter and Garbaye, 1994). Trichoderma fungi can also be expressed in the fungal groups that are effective in the rhizosphere. They are endophytic saprophytes, readily colonize the root surface of the host plant, benefit plant health as biocontrol agents against various fungal pathogens and promote the development of plant growth. (Pandya and Saraf, 2010; Metwally and Al-Amri, 2019).

In this review, the effects of the use of PGPR, Arbiscular mycorrhizal fungi and Trichoderma inoculants in medicinal and aromatic plants on soil fertility, plant nutrient uptake and plant resistance to environmental stresses will be discussed in the light of the literature. Information will be given about the activities of microbial inoculants alone and in combination and the results of the researches carried out on the related species to date.

\section{Plant Growth Promoting Rhizobacteria (PGPR)}

In recent years, the use of microorganisms has gained importance to reduce the need for chemical fertilizers and for sustainable agricultural activities. Of these microorganisms, the group that includes plant growth promoting bacteria (PGPR) directly produces growth promoting substances (hormones, vitamins, enzymes, siderophores), inhibits ethylene synthesis, binds atmospheric nitrogen to the soil, improves iron, organic and inorganic solubility, phosphate. It also increases the resistance of plants to salinity, metal toxicity and pesticide damage. Also, as a bio-agent, it reduces the harmful effects of phytopathogenic microorganisms. It supports plant growth by increasing the solubility and mineralization of microbial metabolites and inorganic and organic phosphorus (Glick et al., 1999; Dobbelaere et al., 2003; Çakmakçı et al., 2006; Çakmakçı et al., 2007).

Medicinal and aromatic plant species are important because they are consumed without much processing and the harvested crop does not contain synthetic compounds. Excessive use of chemical fertilizers has negative effects on plant and soil health. Considering the environmental pollution caused by excessive use of fertilizers and high production costs; Rhizobacteria (PGPR), which is a plant growth promoter, can be used in sustainable agricultural production (Kutlu et al., 2019).

Optimal and balanced mineral fertilization adjusted to the nutritional requirements and growing conditions of medicinal aromatic plants is an important growing factor that determines the amount and quality of essential oil (Nurzynska-Wierdak, 2013). Although bacterial and herbal studies are usually focused on herbaceous plants, studies on medicinal plants are quite scarce. PGPR in medicinal and aromatic plants has been studied in the following plants Origanum majorana L. (Banchio et al., 2008), Rosemary (Leithy et al., 2006), Pelargonium graveolens (Mishra et al., 2010), sweet fennel ( Rezvani Moghaddam et al., 2011), dill (Hellal et al., 2011), mint (Santaro et al., 2011), basil (Ordookhani et al.,2011), coriander (Hassan et al., 2012), Mexican marigold (Cappellari et al., 2013), Thymus daenensis (Bahadori et al., 2013), sage (Ghorbanpour et al., 2016), Turkish thyme (Kutlu et al., 2019). 
Although some studies have addressed the role of PGPR added to medicinal plants (Santoro et al., 2011), it is slightly known about the effect of PGPR on the production of secondary metabolites (Banchio et al., 2008). Moreover, generally, the efficiency of rhizobacteria applications on medicinal plants may be limited or variable (Cappellari et al., 2015).

In a study conducted in Iran the impact of inoculating Ocimum basilicum roots with plant growth-promoting rhizobacteria (PGPR) on plant growth indices such as shoot wet weight, shoot dry weight, root fresh weight, root dry weight, shoot height, N, P and K content and essential oils has been evaluated. PGPR inoculants are Pseudomonas putida strain 41, Azotobacter chroococcum strain5, and Azosprillum lipoferum strain. Compared to the control group, it was stated that all factors increased with maximum root fresh weight $(3.96 \mathrm{~g} /$ plant $), \mathrm{N}$ content $(4.72 \%)$ and essential oil yield $(0.82 \%)$ of PGPR inoculants in Pseudomonas + Azotobacter + Azosprillum application. (Ordokhani, 2011).

Similar results were also obtained in the applications of different varieties of lemongrass with phosphate-solving bacteria (Pseudomonas putida 41, Azotobacter chroococcum 5 and Azosprillum lipoferum). Therefore, it has been determined that the combined use of bacterial isolates provides increases in plant height and biomass (Ratti et al., 2001).

Hassanpour et al. (2012) reported that the growth and yield of the pennyroyal (Mentha pulegium L.) were decreased significantly under water stress, and that some PGPRs applications under stress conditions could increase the secondary metabolites and plant biomass.

In the study, on the Satureja hortensis L. PGPR and humic acid combinations applied under drought stress were able to eliminate many problems caused by drought stress or reduce the effect of stress to fair level. Especially the applications which can effectively provide significant increases for total biomass, essential oil yield and chlorophyll levels even under drought stress conditions was useful (Ghazvini et al., 2014). Agrobacterium sp., Bacillus sp., Pantoea sp. and Pseudomona ssp. Three different bacterial bioformulations (F1, F2 and F3) have been prepared using a total of 19 bacterial isolates. The cloves of garlic (Allium sativum L.) dipped in these bioformulations were planted in pots and the effects of the treatments on plant height, chlorophyll level and some enzyme (catalase, peroxidase, polyphenoloxidase and superoxide dismutase) activities were determined.

It was observed that all bacterial formulation applications made significant contributions to plant growth in garlic and caused significant changes in plant enzyme levels compared to the control groups. (Esringü et al., 2016).

Previous studies have showed that rosemary (Rosmarinus officinalis L.) has antibacterial, antioxidant, antiviral and immune system enhancing effects on the amount of essential oil composition in the rosemary plant by promoting bacterial (Pseudomonas fuorescence) growth stimulation (Gachkar et al., 2007).

The effects of salinity stress on levels were investigated. Contrary to the decreases observed in essential oils in parallel with the increase in salinity levels, it was estimated that the essential oils could remain constant even under the same dose of salinity stress with bacterial applications (Bidgoli et al., 2019).

Asgharia et al. (2020), investigated the effect of PGPR applications on the protection of pennyroyal (Mentha pulegium L.) against drought damage. For this purpose, single and combined uses of Azotobacter chroococcum, Azospirillum brasilense bacteria were performed. In different drought tests, PGPR inoculations significantly reduced the negative effects on low growth parameters and production of secondary metabolites caused by water stress. The results showed that bacteria could have different effects on their ability to improve plant properties and the combination of bacteria may be more effective for improving physiological and phytochemical parameters in pennyroyal.

The results of the studies show that the plant species, the ecology in which the plant grows, and the use of PGPR isolates singly or in combination may drive plant X PGPR isolate interactions.

\section{Arbuscular Mychorrhizal Fungi Inoculation (AMF)}

Endo-mycorrhizae are known as arbuscular mycorrhizae (AM). Their distinctive feature is that they form highly branched structures within the stem cortex cells. Mycorrhizal fungi generally multiply rapidly, both in the root and in the soil. Mycorrhizal relationship is generally observed approximately $92 \%$ of the plants in the world (Isaac, 1992). Today, mycorrhizae are divided into 7 different types: Vesicular arbuscular mycorrhizae, Ectomycorrosis, Ectendomycorrhizae, Ericoid mycorrhiza, Arbutoid mycorrhizae, Monotropoid mycorrhiza, and Orchid mycorrhiza (Anonymous, 2021). Even if vesicular arbuscular mycorrhiza (VAM) and ectomycorrhizae (ECM) are the agriculturally important types, the arbuscular mycorrhizal (AM) symbiosis is probably the most widespread beneficial interaction between plants and microorganisms (Parniske, 2008). In several studies, it was reported that they play a crucial role in plant nutrition and growth in stressed conditions and enhance a few essential ecosystem processes (Siddiqui and Pichtel 2008; Nakmee et al., 2016).

These microorganisms are not only protecting plant roots against pathogenic organisms, but also protect the plant against heavy metal toxicity and salinity stress and increase the plant's resistance (Smith and Read, 1997). Thus, AMF applications on lemongrass (Symbopogon martini) and mint (Mentha piperita) increased the volatile fatty acid amounts and mineral nutrient contents compared to the control group (Qupta et al; 1990; Khaliq and Janardhanan, 1997). Based on the idea that mycorrhizal activity may show variable results in different medicinal aromatic plants, the effect of mycorrhizal symbiosis is also investigated in a total of 76 different medicinal aromatic plant species. Therefore, it was determined that the activity was higher in the vegetative growth stage of the plant than in the flowering and fruiting stages, and the interaction was occurred especially in parallel with a better root development. In addition, it was concluded that herbaceous plants showed more root colonization than shrub and branched plants, and mycorrhizal applications could be observed more clearly in herbaceous plants (Sadiq Gorsi, 2002). 
Among the benefits which are provided by mycorrhizal applications, the increases in the number of seeds and umbrellas, balanced growth, and development, increases in essential fatty acids and positive changes in the chemical composition of the fennel plant have been demonstrated by many studies (Kapoor et al., 2004; El-Ghadban et al., 2006).

Pankaj et al. (2021), in their study on the determination of the effect of AMF colonization on seedling emergence and growth in saline soil, seeds of Palmarosa (Cymbopogon martinii) plant ('Tripta', 'PRC-1' and 'CIMAP-Harsh') were grown in pots inoculated with AMF (Rhizophagus intraradices, Funneliformis mosseae, Glomus aggregatum and Rhizophagus fasciculatus). They have reported that inoculation with AMF significantly improved seed formation, shoot and root development, and viability indices. They stated that $R$. intraradices, 'Tripta' cultivar was the most effective in improving seedling emergence, fresh shoot and root weight and viability index. They stated that AMF colonization in saline soils is suitable for growing healthy seedlings of 'Tripta' and $F$. mosseae varieties and can increase agricultural yield with high economic returns.

Jeet and Baldi. (2012) inoculated the Fennel plant (Foeniculum vulgare), a valuable medicinal plant, with Arbuscular mycorrhizal-like fungi (Sebacina vermifera), Phosphate-solving bacteria (Pseudomonas fluorescens), Azotobacter (Azotobacter chroococcum) in their study. The response of individual microorganism species was evaluated with reference to essential oil emergence, plant growth and yield, along with the qualitative effects on the essential oil. They reported that Sebacina vermifera was relatively important in stimulating the emergence of fennel seeds, growing the plant and increasing the yield of essential oil. They stated that Sebacina vermifera has great potentials for its agro-ecological qualities in medicinal plant cultivation and crop production and increases phytochemical production in medicinal plants. They stated that $S$. vermifera application can increase all positive effects on plant performance and $S$. vermifera application may be a better alternative to traditional chemical-based fertilizers.

AMF affects nutrient and water uptake and cell regeneration as a result of root development and increased absorption capacity of the roots. Apart from phosphorus, it provides the intake of other nutrients such as nitrogen, calcium, copper, manganese, sulfur and zinc (Sieverding, 1991; Ortaş, 2002). Arbuscular mycorrhizal fungi establish a direct physical connection between their external hyphae and host plant and soil. Thanks to these hyphae, they provide not only the uptake of mineral ions from the soil to the plant, but also the uptake of carbon (Kapulnik and Douds, 2000c).

Moreover, they can provide better plant growth and reproduction at the soils which are poor about plant nutrients or inadequate moisture by obtaining the nutrients with extramatrical hyphae. As a result of all these benefits, mycorrhizal plants are generally more resistant to environmental stresses than non-mycorrhizal plants (Kapoor et al., 2004).

AMFs have positive effects on water usage and mineral matter intake as well as overall yield and quality parameters such as germination, biological yield, root yield, essential oil content and essential oil yield and contribute to dry matter accumulation. In some studies, these plants were thought to be leading especially in the pharmaceutical and medicinal sectors. Therefore, to consider these activities, there is a need for future studies on the interactions of AMF, medicinal aromatic plant ecological conditions.

\section{Trichoderma}

Symbiosis takes place between crops and soil microorganisms, including plant growth promoting rhizobacteria (PGPR) and plant growth promoting fungi (PGPF) which are considered as natural bio stimulants. Trichoderma spp. which belongs to a class of PGPF has been successfully used on a commercial scale for biological control of phytopathogens such as Fusarium oxysporum, Rhizoctonia solani, Armillaria mellea and Chondrostereum purpureum (Benítez et al., 2004; ElKomy et al., 2015).

The ability of Trichoderma about to sense, invade, and destroy other fungi has been a major trait behind their commercial success as biopesticides (Verma et al., 2007). Currently, more than $60 \%$ of all registered biopesticides contain a single Trichoderma isolate, or mixtures of Trichoderma species for greater bioactivity. The Trichoderma species are frequently used in biocontrol and the best studied regarding their mechanisms of actionare $T$. asperellum, T. atroviride, T. harzianum, T. virens, and $T$. viride, and most of which also exhibit high biostimulant action on horticultural crops (López-Bucioa et al., 2015). At the same time, because of quickly colonizing in plant roots and competing with phytopathogens for the place of infection or nutrients, Trichoderma fungi produce several substances as antibiotic properties and hydrolytic enzymes (cellulases, chitinases, xylanases, pectinases, $\beta-1,3-$ glucanases, and proteases among others) through which they can. Numerous reports showed that several strains of Trichoderma have a significant reducing effect on plant diseases that are caused by soilborne and foliar pathogens (such as Rhizoctonia solani, Phytophthora spp., Pythium ultimum, Fusarium spp., Alternaria alternata, Sclerotinia spp., Gaeumannomyces graminis, Tielaviopsis basicola, Verticillium dahliae, and Botrytis cinerea) under greenhouse and field conditions (Harman et al., 2004).

Trichoderma spp. helps plants better resist to environmental stresses such as salinity and drought via reinforcing plant growth and reprograming gene expression in roots and shoots. The fungal mycelium secretes different compounds that increase the branching capacity of the root system, thus improving nutrient and water acquisition. Therefore, the products of Trichoderma are used as biopesticide, biofungicide, bioinoculant, biostimulant, biofertilizer and plant growth promoter. Trichoderma is stronger in terms of capacity on carrying and uptaking soil nutrients and making them more effective and competitive than other soil microorganisms. By reducing the $\mathrm{pH}$ of the soil, it allows the uptake of phosphates, iron, manganese, and magnesium elements. Moreover, iron recovery is an important component at microbial competition, especially around the rhizosphere where microbial activities are intense. Also, the species of Trichoderma are gained popularity because of their 
multifaceted efficacy among several microbial biofertilizers and biopesticides.

Application of Trichoderma inoculum at early stage of crop growth permits to maximize its benefits in terms of root development and nutrient uptake. Increases in plant growth following Trichoderma treatment depend on the specific crop or plant genotype. In a study conducted with Trichoderma species and Salvia miltiorrhiza, which are generally focused in horticultural plants, it was determined that the mycelium (EM) extract and polysaccharide fraction (PSF) were produced by Thichoderma atroviride D16 had effects on the growth and secondary metabolism of hairy roots. Furthermore, the results showed that the respective fungal isolate promoted hairy root growth and stimulated the biosynthesis of tanshinons (a biochemical substance extracted from Salvia miltiorrhiza, which has cytotoxicity to various tumor cells) in hairy roots. However, the comparison of efficiency of the distillates obtained with steam proves the positive effect of $T$. asperellum B35 on coriander. It is important that increasing the yield of essential oils does not mean a change in composition and this obtained oil is at the upper ranges of pharmacopoeial standards. At the same time, the usage of antagonistic fungi affects the improvement of biometric parameters of the plant. An increased yield and the number of coriander fruits are found to be at the level of $\sim 60 \%$. In the experimental combination with $T$. asperellum B35 in a study, it was reported that the biomass of the aerial parts of the plant was slightly reduced twice as large inistration the accumulation of some phenolic acids (Ming et al., 2013). Mentha arvensis L. (Family Lamiaceae) was commonly called Japanese mint. In a different study, two strains of Trichoderma were tested for its effects on the growth and productivity of mint plants without using any chemical fertilizers. Trichoderma harzianum (NFCCI 2241) and T. ovalisporum (NFCCI2689) were isolated from soil samples of Mentha growing fields of CIMAP, Hyderabad. At the end, the herbal oil yield and menthol content were found to be the highest and a significant increase with NFCCI 2241 in both crops was occurred and this was more than with NFCCI 2689 (Ratnakumari et al., 2014).

In another study on coriander, biometric parameters and changes in volatile fatty acids were tried to be determined in plants treated with $T$. asperellum B35. The comparison of efficiency of the distillates which were obtained with steam, proved the positive effect of $T$. asperellum $\mathrm{B} 35$ on coriander.

\section{Combined Applications of Microorganism Groups}

In the study for investigating the symbiotic relationship between the inoculation of arbuscular mycorrhizal fungi and phosphate-solubilizating bacteria in the roots of May chamomile (Matricaria chamomilla), an increase in the dominant active ingredients camzulene and bisabolene was reported in parallel with a $28 \%$ increase in essential oil yield with concomitant microorganism applications (Saedi- Farkoosh et al., 2011). Similarly, AMF (Glomus intraradices) and PGPR (Bacillus polymixa, Pseudomonas putida, Azotobacter chroococcum) applications were made in the South African origin stevia (sugar grass) plant, either alone or in combination. The results showed that inoculation with a single microorganism significantly increased root and shoot biomass as well as stevioside, chlorophyll and NPK content in plants compared to control. However, such multiplying effects have been found to be significantly enhanced due to bicompatible inoculant mixtures resulting from their strong synergetic relationships among themselves. The present results also showed that among all plants inoculated in pairs, plants inoculated with AM fungi and PGPR had the maximum K content. In addition, it was determined that triple vaccination had more positive effects on chlorophyll $a, b$ and total content than single vaccination, but the effects were less than double vaccination. Researchers have suggested that competition between microorganisms in triple inoculations reduced the effectiveness of inoculations (Vafadar et al., 2014).

Phytoremediation is the possibility of cultivation by different mechanisms in soils contaminated with heavy metals because of the abilities of some microorganisms and plants. In a study investigating the synergistic effects of plant growth promoting rhizobacteria (Streptomyces, Azotobacter, Pseudomonas and Paenibacillus) and arbuscular mycorrhizal fungi (Glomus, Acaulospora and Scutellospora) on the bioremediation of iron-contaminated soils, pearl millet daisy (Pennisetum bihumorum), it was explained that these microorganism groups were effective on the phytoremediation of soil which was contaminated with $\mathrm{Fe}^{+3}$ compared to control. The effects of concomitant use of AMF and plant growth promoting rhizobacteria species on plant growth also showed a higher phytoremediation efficiency than single usage. It has been stated that these might be due to the siderophore hormone that was produced by all microorganisms (Mishra et al., 2016).

The interaction of the use of AMF and Trichoderma viride at onions on biomass, total soluble protein, mycorrhizal colonization, amino acids, and phosphorus nitrogen content were investigated. Similarly, the combination of AMF and Trichoderma was caused a significant increase in total biomass, free amino acid, and soluble protein contents (Metwally et al., 2021). The potential of single or combined application of Trichoderma harzianum and Stenotrophomonas spp (Az-30), Bacillus flexus (Sd-30) and Brevibacterium halotolerans (Sd6) strains on growth and essential oil yield on Japanese mint (Mentha arvensis) was also evaluated. In vitro interaction studies were shown that it did not antagonize Trichoderma harzianum (Th) individually and didn't prove the possibility of using these combinations for plant growth. Furthermore, it was revealed that in vitro inoculation of Trichoderma harzianum and Brevibacterium halotolerans (Sd6) strains increased plant growth, oil content, petiole ratio, photosynthetic pigments, and nutrient uptake, and resulted in higher oil yield than other microbial treatments. The results demonstrated synergistic interactions between Brevibacterium halotolerans and Trichoderma harzianum while improving survival, plant growth and yield. It was determined that the same combination application had similar effects in field conditions (Singh et al., 2019).

Solanum viarum (Tropical soda apple) seedlings was evaluated based on the interaction between AMF (Glomus aggregatum), PGPR (Bacillus coagulans) and Trichoderma harzianum, maximum plant biomass of 
combined uses of $G$. aggregatum + B. coagulans $+T$. harzainum (dry shoot and root weight-12.17 g). As a result the lowest biomass was recorded in the control and maximum percentage of maximum root colonization was seen $G$. aggregatum $+B$. coagulans + T.harzianum inoculated plants. Plant height $(60.5 \mathrm{~cm})$ was significantly increased in $G$. aggregatum + B. coagulans $+T$. harzianum triple inoculation and also the maximum number of spores was recorded in plants inoculated with G. aggregatum + B. coagulans and G. aggregatum $+B$. coagulans T.harzianum. Moreover, phosphorus, potassium, zinc, copper, manganese, and iron contents of leaf samples were reported to be highest in plants treated with G. Aggregatum + B. coagulans $+T$. harzianum as opposed to plants inoculated with $G$. aggregatum alone (Hemashenpagam, 2011).

\section{Conclusion and Future Aspects}

As a conclusion, especially, the possibilities of increasing or changing the growth, yield, essential oil content and components of medicinal and aromatic plants have not been extensively investigated using multi-specific bacteria.

The clear conclusion from the above considerations is that stressful environments can cause nutritional and hormonal imbalances in the cultivation of medicinal and aromatic plants resulting in a negative impact on plant growth and development. However, the stress-induced negative effect on plant growth can be mitigated and/or minimized by naturally occurring microorganisms such as PGPR, AMF and Trichoderma. Recently, proteomicsbased techniques have opened an important door to reveal the molecular mechanisms of various abiotic stress responses. Several stress sensitive proteins are suggested for the plant using these techniques. Moreover, by using these proteins and their corresponding genes, it may be possible to produce stress-resistant medicinal plants soon.

Moreover, identification of genes which are controlled with stress tolerance traits in these microorganisms will also increase our knowledge of the molecular basis of stress tolerance mechanisms. Therefore, in many in vitro studies, it would be a positive step to register the relevant biochemical and physiological mechanisms of the stress factor. The early studies with microorganisms have also led to variable results in much information.

The areas that researchers should focus on might be turning to microorganism-based metabolite engineering in stressful environments, discovering which microorganism strains are beneficial for promoting plant growth, which should be used singly, and which should be used in combination, identifying target genes to promote growth under stress, and transferring target genes to plants through biotechnology (Shazad et al., 2015).

\section{References}

Anonymous 2021. The Microbial World: Mycorrhizas. (Produced by J. Deacon). http://helios.bto.ed.ac.uk/bto/ microbes/mycorrh.htm

Asghari B, Khademian R, Sedaghati B. 2020. Plant growth promoting rhizobacteria (PGPR) confer drought resistance and stimulate biosynthesis of secondary metabolites in pennyroyal (Mentha pulegium L.) under water shortage condition. Sci. Horticul. 263: 109132.
Aziz EA, Hendawi ST, Azza EED, Omer EA. 2008. Effect of soil type and irrigation intervals on plant growth, essential oil and constituents of Thymus vulgaris plant. Am. Euras. J. Agric. Environ. Sci 4: 443-450.

Bahadori F, Ashorabadi ES, Mirza M, Matinizade M, Abdosi V. 2013. Improved growth, essential oil yield and quality in Thymus daenensis Celak on mycorrhizal and plant growth promoting rhizobacteria inoculation. International Journal of Agronomy and Plant Production 4: 3384-3391.

Banchio E, Bogino PC, Zygadlo J, Giordano W. 2008. Plant growth promoting rhizobacteria improve growth and essential oil yield in Origanum majorana L. Biochemical Systematics and Ecology 36: 766-771.

Benítez T, Rincón AM, Limón MC, Codón AC. 2004. Biocontrol mechanisms of Trichoderma strains. Int. Microbiol. 7: 249-260.

Bidgoli DR, Azarnezhad N, Akhbari M, Ghorbani M. 2019. Salinity stress and PGPR efects on essential oil changes in Rosmarinus of cinalis L. Agric and Food Secur 8:2

Briskin DP. 2000. Medicinal plants and phytomedicines. Linking plant biochemistry and physiology to human health. Plant Physiol 124:507-514

Bray EA, Bailey-Serres J, Weretilnyk E. 2000. Responses to abiotic stresses. In: Gruissem W, Buchannan B, Jones R. (Eds.), Biochemistry and Molecular Biology of Plants. American Society of Plant Biologists, Rockville, MD, pp. $158-1249$

Cappellari LDR, Santoro MV, Nievas F, Giordano W, Banchio E. 2013. Increase of secondary metabolite content in marigold by inoculation with plant growth-promoting rhizobacteria. Applied Soil Ecology 70: 16-22.

Cappellari LDR, Santoro MV, Reinoso H, Travaglia C, Giordano W, Banchio E. 2015. Anatomical, morphological, and phytochemical effects of inoculation with plant growthpromoting rhizobacteria on peppermint (Mentha piperita). Journal of Chemical Ecology 41: 149-158.

Cole IB, Saxena PK, Murch SJ. 2007. Medicinal biotechnology in the genus scutellaria. In Vitro Cell Dev Plant.;43:318-27.

Croteau R, Kutchan TM, Lewis NG. 2000. Natural products (secondary metabolites). Biochemistry and molecular biology of plants, 24: 1250-1319.

Çakmakçı R, Donmez F, Aydin A, Sahin F. 2006. Growth promotion of plants by plant growth-promoting rhizobacteria under greenhouse and two different field soil conditions. Soil Biology and Biochemistry, vol.38, no.6, pp.1482-1487

Çakmakçı R, Donmez MF, Erdogan U. 2007. The effect of plant growth promoting rhizobacteria on barley seedling growth, nutrient uptake, some soil properties, and bacterial counts. Turkish Journal of Agriculture and Forestry, vol.31, no.3, pp.189-199

Dobbelaere S, Vanderleyden J, Okon Y. 2003. Plant growth promoting effects of diazotrophs in the rhizosphere. Crit Rev Plant Sci, 22:107-149.

Esringü A, Kaynar D, Turan M, Ercisli S. 2016. Ameliorative effect of humic acid and plant growth-promoting rhizobacteria (PGPR) on hungarian vetch plants under salinity stress. Communications in Soil Science and Plant Analysis, 47(5): 602-618.

El-Ghadban EAE, Shalan MN, Abdel-Latif TAT. 2006. Influence of biofertilizers on growth, volatile oil yield and constituents of fennel (Foeniculum vulgare Mill.). Egyptian Journal of Agricultural Research, 84(3): 977- 992.

El-Komy MH, Saleh AA, Eranthodi A, Molan YY. 2015. Characterization of novel Trichoderma asperellum isolates to select effective biocontrol agents against tomato Fusarium wilt. Plant Pathol. J. 31: 50-60.

Ertürk Y, Ercisli S, Sekban R, Haznedar A, Dönmez MF 2008. The effect of Plant Growth Promoting Rhizobacteria (PGPR) on rooting and root growth of tea Camellia sinensis var sinensis cuttings. Romanian Biotechnological Letters. 13(3): 3747-3756. 
Ertürk Y, Ercisli S, Haznedar A, Çakmakçı R. 2010. Effects of plant growth promoting rhizobacteria PGPR on rooting and root growth of kiwifruit Actinidia deliciosa stem cuttings. Biological Research, 42(1): 91-98.

Fitter AH, Garbaye J. 1994. Interactions between mycorrhizal fungi and other soil organisms. Plant and Soil 159: 123-132.

Figueiredo MSL, Grelle CEV. 2009. Predicting global abundance of a threatened species from its occurrence: implications for conservation planning. Divers Distrib.15: 117-21

Flexas J, Bota J, Loreto F, Cornic G, Sharkey TD. 2004. Diffusive and metabolic limitations to photosynthesis under drought and salinity in C3 plants. Plant Biology 6: 269-279.

Gachkar L, Yadegari D, Rezaei MB, Taghizadeh M, Astaneh SA, Rasooli I. 2007. Chemical and biological characteristics of Cuminum cyminum and Rosmarinus officinalis essential oils. Food Chem., 102(3): 898-904.

Ghazvini SN, Pazoki A, Tajali A. 2014. Study the effect of Plant Growth promoting Rhizobacteria (PGPR) and Humic acid for some savory (Satureja hortensis L.) plant Physiological traits under Drought stress. Bull. Env. Pharmacol. Life Sci., 3(3): 182-185

Glick BR, Patten CL, Holguin G, Penrose DM. 1999. Biochemical and genetic mechanisms used by plant growth promoting bacteria. Imperial College Press, London, pp $1008-1015$

Goldman P. 2001. Herbal medicines today and the roots of modern pharmacology. Ann Int Med 135:594-600.

Ghorbanpour M, Hatami M, Kariman K, Dahaji PA. 2016. Phytochemical variations and enhanced efficiency of antioxidant and antimicrobial ingredients in Salvia officinalis as noculated with different rhizobacteria. Chem. Biodiversity 13: $319-330$.

Harman GE, Howell CR, Viterbo A, Chet I, Lorito M. 2004. "Trichoderma species opportunistic, avirulent plant symbionts," Nature Reviews Microbiology, vol. 2, no. 1, pp. 43-56.

Hassan F, Ali E, Mahfouz S. 2012. Comparison between different fertilization sources, irrigation frequency and their combinations on the growth and yield of coriander plant. Australian journal of basic and applied sciences 6: 600-615.

Hassanpour H, Khavari-Nejad RA, Niknam V, Najafi F, Razavi K. 2012. Effects of penconazole and water deficit stress on physiologial and antioxidative respomses in pennyroyal (Mentha pulegiımL.). Acta physiol. Plant .34: 1537-154

Hellal F, Mahfouz S, Hassan F. 2011. Partial substitution of mineral nitrogen fertilizer by bio-fertilizer on (Anethum graveolens L.) plant. - Agriculture and Biology Journal of North America 2: 652-660.

Hemashenpagam N. 2011. Effect of arbuscular mycorrhizal (AM) fungus and plant growth promoting rhizomicroorganisms (PGPR's) on medicinal plant Solanum viarum seedlings. J. Environ. Biol. 32, 579-583 ISSN: 0254-8704 CODEN: JEBIDP

Heidari F, Salmasi SZ, Javanshir A, Aliari H, Dadpoor MR. 2008. The effects of application microelements and plant density on yield and essential oil of Peppermint (Mentha piperita L.). Iran J. Med. Arom. Plant 24: 1-9.

Isaac S. 1992. Fungal Plant Interactions. Chapman and Hall, London, UK, p.418.

Kapoor R, Giri B, Mukerji KG. 2004. Improved growth and essential oil yield and quality in Foeniculum vulgare Mill. on mycorrhizal inoculation supplemented with $\mathrm{P}$ fertilizer. Bioresource Technology, 93: 307- 311.

Kapulnik Y, Douds DD. Jr (eds.) 2000. Arbuscular Mycorrhizas: Physiology and Function.Kluwer Academic Publishers. Printed in the Netherlands.p: 3-18.

Khaliq A, Janardhanan KK. 1997. Influence of Vesicular Arbuscular Mycorrhizal Fungi on the Productivity of Cultivated Mints. Journal of Medicinal and Aromatic Plants Science, 19: 7-10.
Kutlu M, Çakmakçı R, Hosseinpour A, Karagöz H. 2019. The use of plant growth promoting rhizobacteria (PGPR)'s effect on essential oil rate, essential oil content, some morphological parameters and nutrient uptake of Turkish oregano. Appl Ecol Env Res 17:641-1653

López-Bucioa J, Pelagio-Floresa R, Herrera-Estrellab A. 2015. Trichoderma as biostimulant: exploiting the multilevel properties of a plant beneficial fungus. Scientia Horticulturae 196:109-123.

Leithy S, El-Meseiry T, Abdallah E. 2006. Effect of biofertilizer, cell stabilizer and irrigation regime on rosemary herbage oil yield and quality. - Journal of Applied Sciences Research 2: 773-779.

Lichtenhaler HK. 1996. Vegetation stress: An introduction to the stress concept in plants. J Plant Physiol,148: 4-14.

Metwally RA, Al- Amri SM. 2019. İnduvial and interactive role of Trichoderma viride and arbuscular mychorizal fungi on growth and pigment content of onion plants. Lett.Appl. Microbiol.70:79-86

Metwally RA, Soliman AS, Abdel Latef AAH, Abdelhameed ER. 2021. The individual and interactive role of arbuscular mycorrhizal fungi and Trichoderma viride on growth, protein content, amino acids fractionation, and phosphatases enzyme activities of onion plants amended with fish waste. Ecotoxicology and Environmental Safety 214: 112072

Ming O, Su C, Zheng C, Jia M, Zhang O, Zhang H, Rahman K, Han T, Qin L.2013. Elicitors from the endophytic fungus Trichoderma atroviride promote Salvia miltiorrhiza hairy root growth and tanshinone biosynthesis. Journal of Experimental Botany, 64(18): 5687-5694,

Mishra RK, Prakash O, Alam M, Dikshit A. 2010. Influence of plant growth promoting rhizobacteria (PGPR) on the productivity of Pelargonium graveolens 1 . herit. - Recent research in science and technology 2(5): 53-47.

Mishra V, Gupta A, Kaur P, Singh S, Singh N, Gehlot P, Singh L. 2016. Synergistic effects of Arbuscular mycorrhizal fungi and plant growth promoting rhizobacteria in bioremediation of iron contaminated soils. International Journal of Phytoremediation, 18(7): 697-703

Nakmee PS, Techapinyawat S, Ngamprasit S. 2016. Comparative potentials of native arbuscular mycorrhizal fungi to improve nutrient uptake and biomass of Sorghum bicolor Linn. Agric. Nat. Resour. 50:173-178.

Nurzynska-Wierdak R. 2013. Does Mineral Fertilization Modify Essential Oil Content and Chemical Composition in Medicinal Plants - ACTA Scientiarum Polonorum Horticulture 12: 3-16.

Ordookhani K, Sharafzadeh S, Zare M. 2011. Influence of PGPR on growth, essential oil and nutrients uptake of sweet basil. Advances in Environmental Biology 5: 672-677.

Ortíz-Castro R, Contreras-Cornejo HA, Macías-Rodríguez L, López-Bucio J. 2009. The role of microbial signals in plant growth and development. PlantSignal. Behav. 4: 701-12.

Pandya U, Saraf M. 2010. Application of fungi as a biocontrol agent and their biofertilizer potential in agriculture.J. Adv.Dev. Res. 1(1):90-99.

Parniske M. 2008. Arbuscular mycorrhiza: The mother of plant root endosymbioses. Nat. Rev. Genet. 6: 763-775.

Pagare S, Bhatia M, Tripathi N, Pagare S, and Bansal YK.2015. Secondary metabolites of plants and their role: overview. Curr. Trends Biotechnol. Pharm. 9: 294-304.

Pankaj U, Kurmi A, Lothe BN, Verma KR. 2021. Influence of the seedling's emergence and initial growth of palmarosa (Cymbopogon martinii (Roxb.) Wats. var. Motia Burk) by arbuscular mycorrhizal fungi in soil salinity conditions. Journal of Applied Research on Medicinal and Aromatic Plants 24: 100317.

Ortaş İ. 2002. Do Plants Depend on Mycorrhizae in Terms of Nutrient Requirement? International Conference on Sustainable Land Use and Management. Çanakkale 
Qupta ML, Janardhanan KK, Chattopadhyay A, Hussain A. 1990. Associations of Glomus with palmrosa and its influence on growth and biochemical production. Mycological Research, 561-563.

Ratti N, Kumar S, Verma HN, Gautam SP. 2001. Improvement in bioavailability of tricalcium phosphate to Cymbopogon martini var. motiaby Rhizobacteria, AMF and Azospirillum Inoculation. Microbiological Research, 156: 145- 149

Ratnakumari RY, Nagamani A, Sarojini CK, Adinarayana G. 2014. Effect of Trichoderma species on yield of Mentha arvensis L. International Journal of Advanced Research, Volume 2, Issue 7: 864-867. ISSN 2320-5407.

Rezvani Moghaddam P, Nassiri Mahallati M, Nezhadali A. 2011. Effects of organic and biological fertilizers on fruit yield and essential oil of sweet fennel (Foeniculum vulgare var. dulce). - Spanish Journal of Agricultural Research 9: 546-555.

Sadiq-Gorsi M. 2002. Studies on mycorrhizal association in some medicinal plants of Azad Jammu and Kashmir. Asian Journal of Plant Science, 14: 383- 38

Saedi-Farkoosh S, Ardakani MR, Rejali F. 2011. Effect of mycorrhizal symbiosis and bacillus coagolance on qualitative and quantitative traits of Matricaria chamomilla under different levels of phosphorus. Middle East Journal of Scientific Research, 8: 19.

Santoro MV, Zygadlo J, Giordano W, Banchio E. 2011. Volatile organic compounds from rhizobacteria increase biosynthesis of essential oils and growth parameters in peppermint (Mentha piperita). - Plant Physiology and Biochemistry 49: $1177-1182$.

Singh S, Tripathi A, Maji D, Awasthi A, Vajpayee P, Kalr A. 2019. Evaluating the potential of combined inoculation of Trichoderma harzianum and Brevibacterium halotolerans for increased growth and oil yield in Mentha arvensis under greenhouse and field conditions. Industrial Crops and Products 131: 173-181.
Shazad SM, Arif MS, Ashraf M, Abid M, Ghazanfar MU, Riaz M, Yasmeen T, Zahid MA. 2015. Alleviation of abiotic stress in mediclinal plants by PGPR. Plant-Growth-Promoting Rhizobacteria (PGPR) and Mediclinal Plants. Eds. Egamberdiva D, Shrivastava S, Varma A. Springer ISSN6133382: 135-166.

Siddiqui ZA, Pichtel J. 2008. Mycorrhizae: An Overview. In Mycorrhizae: Sustainable Agriculture and Forestry; Springer Science and Business Media LLC: Berlin, Germany, pp. 135.

Smith S, Read DJ. 1997. Mycorrhizal Symbiosis. Second Edition. Academic Pres. London.

Sieverding E. 1991. Vesicular-Arbuscular Mycorrhizae Management in Tropical Agrosystems. Technical Cooperation. Federal Rebpublic of Germany 372 pp.

Jeet K, Baldi A. 2021.Potential of Microbes Containing Formulations to Alter Growth and Phytochemicals of Medicinal Aromatic Plant- Foeniculum Vulgare. ijlpr 2020; doi 10.22376/ijpbs/lpr.11.1. P34-51.

Vafadar F, Amooaghaie R, Otroshy M. 2014. Effects of plantgrowth-promoting rhizobacteria and arbuscular mycorrhizal fungus on plant growth, stevioside, NPK, and chlorophyll content of Stevia rebaudiana. Journal of Plant Interactions. Vol. 9, No. 1: 128-136.

Verma M, Brar S, Tyagi R, Surampalli R, Valero J. 2007. Antagonistic fungi,Trichoderma spp.: panoply of biological control. Biochem. Eng. J. 37: 1-20.

Winkel-Shirley B. 2001. Flavonoid biosynthesis. A colorful model for genetics, biochemistry, cell biology, and biotechnology. Plant physiology, 126(2): 485-493.

Yazdani D, Jamshidi MF. 2002.Compare of essential oil yield and menthol existent in Peppermint (Mentha piperita L.) planted in different origin of Iran. J. Med. Plant Med. Plant Inst. Jahadda Neshgahi 3: 73-78. 